\title{
LEARNING AGILITY PADA KARYAWAN GENERASI MILENIAL DI JAKARTA
}

\author{
Devi Jatmika ${ }^{1}$, Karentia Puspitasari² \\ ${ }^{1}$ Program studi Psikologi, Universitas Bunda Mulia \\ Email: dephey@gmail.com \\ ${ }^{2}$ Program studi Psikologi, Universitas Bunda Mulia \\ Email: karen.kirei@gmail.com
}

\begin{abstract}
ABSTRAK
Globalisasi mengakibatkan perkembangan dunia ekonomi dan bisnis bergerak sangat cepat, dinamis dan terus berubah. Generasi milenial atau generasi Y merupakan generasi terbanyak saat ini dan menjadi aset bagi kemajuan perusahaan. Sehingga, untuk menghadapi tantangan perubahan ini, generasi milenial memerlukan learning agility, yaitu kesediaan untuk belajar dan menerapkan hal yang telah dipelajari dalam situasi baru. Sikap karyawan generasi milenial di dunia kerja dalam menghadapi perubahan-perubahan perlu diteliti sehingga organisasi lebih dapat memahami karayawannya. Tujuan dari penelitian ini adalah untuk mengetahui tingkat learning agility pada karyawan generasi milenial di Jakarta. Metode penelitian yang digunakan adalah metode penelitian kuantitatif deskriptif. Alat ukur penelitian disusun berdasarkan empat dimensi learning agility learning agility yang terdiri dari people agility, results agility, change agility, dan mental agility. Teknik sampling yang digunakan adalah convenience sampling. Partisipan dalam penelitian adalah 136 orang karyawan tetap generasi milenial berusia $18-37$ tahun. Teknik analisa data deskriptif menggunakan perbandingan mean hipotetik dan mean empirik serta uji perbedaan dengan independent sample t-test dan one-way ANOVA. Hasil penelitian menunjukkan learning agility karyawan generasi milenial berada pada kategori tinggi. Skor rata-rata mental agility merupakan skor paling tinggi diikuti dengan results agility, change agility dan skor rata-rata people agility terendah. Uji perbedaan ditemukan tidak ada perbedaan learning agility berdasarkan usia dan jenis kelamin.
\end{abstract}

Kata Kunci: learning Agility, karyawan, generasi milenial

\begin{abstract}
Globalization promotes rapid, dynamic, and constantly changing development in the economic and business world. Being the current most prominent generation, the millennial generation, also known as generation $Y$ serves as an asset for company development. Therefore, in order to overcome this challenge of change, the millennial generation requires learning agility, which $i$ a willingness to learn and apply what has been learned in new situations. The work attitude of the millennial generation in overcoming change still requires investigation, that organizations can have better understanding of their employees. The purpose of this study was to determine the level of learning agility of millennial employees in Jakarta. The research method used was descriptive quantitative research. The research instrument was constructed based on four dimensions of learning agility, namely = people agility, results agility, change agility, and mental agility. The sampling technique used was convenience sampling. Participants of the study were 136 millenials who worked as full-time employees aged 18-37 years. Descriptive data analysis was conducted by comparing hypothetical mean and empirical mean, along with differential test with independent sample t-test and one-way ANOVA. Results show that the learning agility of millennial generation employees was considered high. The mean score of mental agility was the highest, followed by results agility, change agility and the lowest mean score was people agility. The differential test found no differences in learning agility based on age and gender.
\end{abstract}

Keywords: learning agility, employees, millennial generation 


\section{PENDAHULUAN}

\section{Latar Belakang}

Perkembangan ekonomi global saat ini berkembang dengan sangat cepat. Keadaan dunia ekonomi dan bisnis masa kini digambarkan dengan istilah VUCA world. Era VUCA merupakan singkatan dari Volatility, Uncertainty, Complexity dan Ambiguity (Johansen dalam Azzaini, 2018). Volatility adalah dinamika perubahan yang sangat cepat dalam berbagai hal seperti sosial, ekonomi dan politik. Uncertainty yaitu sulitnya memprediksi isu dan peristiwa yang saat ini sedang terjadi, Complexity adalah keadaan yang sangat kompleks karena banyaknya hal-hal yang sangat sulit diselesaikan. Terakhir, Ambiguity yakni keadaan yang terasa mengambang dan kejelasan yang masih dipertanyakan (Johansen dalam Azzaini, 2018). Perusahaan-perusahaan berupaya mempersiapkan organisasinya untuk menghadapi tantangan-tantangan di era VUCA. Pengaruh dari VUCA turut mempengaruhi bidang sumber daya manusia. Karyawan yang bertalenta menjadi unggulan dan penentu perubahan, untuk menghadapi situasi yang penuh ketidakpastian dibutuhkan individu yang bisa bertahan yaitu mereka yang dapat menyesuaikan diri ("Persiapan HRD Menghadapi", 2015).

Dalam pengembangan sumber daya manusia, angkatan kerja di Indonesia saat ini terdiri dari individu yang berasal dari berbagai generasi diantaranya generasi Baby Boomers, Generasi X (1965-1980), Generasi Y (Milenial), dan Generasi Z (di atas tahun 2000). Istilah generasi mengacu pada sekelompok orang-orang yang berada di rentang usia yang sama, mengalami pengalaman kemasyarakatan seperti situasi ekonomi, peristiwa sejarah, nilai budaya yang dominan, budaya populer dan nilai-nilai dalam keluarga dan pertemanan turut membentuk sebuah generasi dan menciptakan suatu susunan nilai-nilai yang unik. Sehingga, generasi umumnya didefinisikan dengan periode kelahiran yang kemudian mengacu pada umur (Strauss \& Howe, 1991; Pinzaru, Vatamanescu E-M, \& Mitan, 2016). Menurut Badan Keluarga Berencana Nasional (BKKBN), Indonesia akan memiliki bonus demografi dengan rentang waktu antara 2020-2030. Pada saat itu usia angkatan kerja 15-64 tahun mencapai 70 persen, sedangkan sisanya 30 persen merupakan penduduk yag tidak produktif (Kementerian Pemberdayaan Perempuan dan Perlindungan Anak \& Badan Pusat Statistik, 2018). Generasi Milenial menjadi angkatan kerja terbesar di Indonesia.

Berdasarkan data BPS di tahun 2016, dari total jumlah angkatan kerja di Indonesia yang mencapai 160 juta, hampir 40\% diantaranya tergolong milenial yaitu sebesar 62,5 juta berusia 20-34 tahun. Sementara itu, 34, 83\% adalah generasi X (usia 35-54 tahun), 24, 18\% adalah generasi baby boomers (usia 55 tahun ke atas) dan 4,8\% adalah generasi $\mathrm{Z}$ (berusia di bawah 20 tahun). Hal ini berarti generasi milenial mendominasi angkatan kerja di Indonesia. Menurut Sunarsihanto (2017) generasi milenial merupakan potensi yang menentukan masa depan perusahaan dan yang berapapun usia karyawan yang terpenting adalah kemampuan dan kemauan karyawan dalam belajar (Hari, 2017). KPMG International (2017) dalam artikelnya menyatakan bahwa generasi milenial adalah generasi yang sesuai dengan sebutannya, lahir pada tahun milenial yaitu antara tahun 1980-2000 dan diharapkan mencapai masa dewasanya pada abad ke 21. Generasi milenial ini sering disebut dengan Generasi Y. Sementara menurut Frey (2018), generasi milenial mengacu kepada generasi dengan tahun kelahiran antara 1981 sampai dengan 1997. Generasi milenial menurut Ali dan Purwandi (2016) dalam Indonesia 2020 : The Urban Middle-Class Millenials, adalah generasi yang lahir antara tahun 1981-2000, atau yang saat ini berusia 15 tahun hingga 34 tahun dan di tahun 2020, generasi milenial berada pada rentang usia 20 tahun hingga 40 tahun. Lebih lanjut, generasi milenial tergolong generasi yang berbeda dengan generasi lain karena mereka banyak dipengaruhi oleh munculnya smartphone, meluasnya 
internet dan munculnya media sosial sehingga mempengaruhi pola pikir, nilai-nilai dan perilaku yang dianut (Ali \& Purwandi, 2016).

Berbagai penelitian mengenai karakteristik generasi $\mathrm{Y}$ atau generasi milenial di Barat, diketahui pada perspektif kepribadian, generasi milenial lebih cenderung narsistis yang ditunjang juga dengan kecenderungan memiliki self esteem yang tinggi, namun kebutuhan untuk pengakuan sosialnya juga cukup tinggi (Twenge et al; Twenge \& Campbell, 2008 dalam Wicaksono, 2017). Generasi milenial lahir pada era teknologi informasi dan teknologi bagian dari hidup mereka. Mereka lebih menyukai komunikasi melalui pesan instan dan cara belajar melalui video/ komputer. Generasi milenial adalah tipe-tipe orang yang multitasking, menyukai kehidupan dinamis dan bergerak cepat (Widhianingtanti, 2017). Penelitian yang dilakukan oleh Prabowo, Latifah, dan Rahmadiani (2017) mengenai kepribadian generasi Y dengan usia kelahiran 19901994 diketahui generasi ini merupakan pribadi yang kreatif, dinamis, optimis terhadap keinginan, fleksibel dalam lingkup sosial dan hal-hal baru, menyukai hal praktis namun kurang memiliki daya juang dan cenderung berorientasi pada dirinya sendiri. Walaupun generasi milenial dinamis, kreatif dan cakap terhadap teknologi, tetapi terdapat kekhawatiran akan sikap mental dari generasi milenial ini. Survey yang dilakukan oleh Catsouphes, Matz-Costa dan Besen (2009) kepada 1.843 responden dengan lintas generasi di Amerika, diketahui generasi milenial atau generasi Y (usia 26 tahun ke bawah) lebih sedikit yang menyatakan pekerjaan mereka bermakna dan memiliki tujuan.

Dalam dunia yang cepat berubah, transisi dan perkembangan menjadi hal yang menantang karena individu menghadapi situasi yang tidak diketahui yang mana rutinitas dan kepemimpinan saat ini menjadi tidak sesuai untuk menghadapi perubahan. Individu yang tidak dapat melepaskan pola-pola perilaku lama dan mengenal perbedaan-perbedaan cenderung akan gagal (De Meuse, Dai, \& Hallenbeck, 2010). Generasi milenial sebagai angkatan kerja produktif terbesar ini turut memiliki andil dalam menghadapi era VUCA. Menurut Sakar (2016), faktor penting untuk suskes dalam era VUCA terdiri dari dasar bisnis yang sehat, inovasi, respons yang cepat, fleksibilitas, manajemen perubahan, pengelolaan SDM yang beragam baik di level lokal dan global, market intelligence dan kolaborasi yang kuat dengan stakeholder. Tantangan bagi organisasi adalah menciptakan kepemimpinan yang agile di masa depan untuk menghadapi perubahan, kolaborasi antar generasi dalam proses kerja, menjalankan peran, berbagi pengetahuan dan informasi (Kornelsen, 2019). Generasi milenial perlu memiliki kemampuan learning agility agar dapat memenuhi tuntutan organisasi akan SDM yang agile. Agility berhubungan dengan menghadapi kesulitan dengan memiliki fleksibilitas, kelincahan untuk melihat solusi-solusi yang ada. Learning agility didefinisikan sebagai kesediaan dan kemampuan untuk belajar dari pengalaman, kemudian menerapkan apa yang telah dipelajari untuk memperoleh kesuksesan di situasi yang baru (Lombardo \& Eichinger, dalam De Meuse, Dai \& Hallenbeck, 2010). Orang-orang dengan agility yang tinggi mengambil pelajaran yang tepat dari pengalaman mereka dan menerapkan pelajaran tersebut di situasi-situasi baru, mereka cenderung akan mencari tantangan-tantangan baru terus menerus, aktif mencari feedback dari orang lain dengan tujuan untuk bertumbuh dan berkembang, cenderung merefleksi diri, dan mengevaluasi pengalaman dan menarik kesimpulan (De Meuse, et al., 2010).

Learning agility terbagi dalam empat dimensi yaitu: 1). People agility: sejauh mana seseorang mengetahui dirinya dengan baik, belajar dari pengalaman, memperlakukan orang lain secara konstruktif dan resilien dalam tekanan perubahan; 2). Results agility: sejauh mana seseorang yang mendapatkan hasil di bawah kondisi yang sulit, menginspirasi orang lain, dan membangun kepercayaan diri orang lain dengan kehadirannya; 3). Mental agility: sejauh mana individu 
berpikir tentang suatu masalah dari sudut pandang yang baru dan merasa nyaman dengan ambiguitas, kompleksitas dan menjelaskan pemikiran mereka kepada orang lain; 4) Change agility: tingkat yang mana individu ingin tahu, memiliki gairah atas ide-ide dan terlibat dalam aktivitas pengembangan keterampilan (Lombardo \& Eichinger dalam De Rue, Ashford, \& Myers, 2012). Mitchinson dan Morris (2014) menjelaskan lima aspek learning agility yang mencakup: 1). Innovating: tidak takut untuk menantang status quo; 2) Performing: Tetap tenang dalam menghadapi kesulitan; 3) Reflecting: Mengambil waktu untuk merefleksikan pengalaman; 4) Risking: Dengan sengaja menempatkan dirinya dalam situasi yang menantang. Dalam penelitian Lombardo dan Eichinger (2000) kepada 217 karyawan diperoleh adanya hubungan keempat dimensi learning agility terhadap potensi kinerja karyawan di perusahaan. Eichinger dan Lombardo (2004), dari penelitiannya diketahui learning agility tidak berhubungan dengan kemungkinan seseorang akan mendapatkan promosi di perusahan. Akan tetapi, learning agility yang dimiliki oleh karyawan dengan kinerja tinggi cenderung lebih tinggi dibandingkan karyawan dengan kinerja rendah dan sedang. Oleh karena itu, learning agility tinggi dapat memprediksi karyawan mendapatkan tantangan dalam promosi. De Meuse, Dai, Hallenbeck, dan Tang (2008), diketahui skor learning agility tidak berhubungan dengan jenis kelamin, tetapi manager perempuan memiliki skor people agility yang lebih tinggi dibandingkan manager lakilaki. Begitupula, learning agility dengan usia Lombardo dan Eichinger (dalam De Meuse, Dai, \& Hallenbeck, 2010) agility menemukan bahwa individu yang lebih muda cenderung memiliki skor yang lebih tinggi dalam aspek change agility ketimbang individu dengan usia yang lebih tua. Dai, De Meuse, Clark dan Cross (dalam De Meuse, 2017) meneliti lebih lanjut kepada 187 manager dari perusahaan farmasi global ditemukan bahwa learning agility manager meningkat dipengaruhi oleh dukungan atasan untuk berubah, budaya dan struktur organisasi yang mendukung. Meskipun penelitian sebelumnya telah dilakukan di negara Barat, penelitian learning agility masih terus berkembang, selain itu belum adanya kajian learning agility di Indonesia.

Berdasarkan uraian sebelumnya, penelitian ini bertujuan untuk menganalisa tingkat learning agility pada karyawan di Indonesia terutama generasi milenial. Dari penelitian ini memberikan sumbangan pengetahuan sejauh mana generasi milenial agile penting mengingat Indonesia sedang menghadapi era VUCA dan tantangannya bagi generasi milenial. Penelitian-penelitian mengenai learning agility perlu dilakukan agar para praktisi di industri organisasi lebih dapat memahami jenis-jenis learning agility pada karyawan dan mengembangkan potensi sumber daya yang mereka miliki.

\section{METODE PENELITIAN}

Metode penelitian yang digunakan dalam penelitian ini adalah metode penelitian kuantitatif dengan jenis penelitian deskriptif. Teknik sampling yang digunakan dalam penelitian ini adalah convenience sampling, yaitu pengambilan sampel berdasarkan kesediaan responden untuk mengisi kuesioner (Gravetter \& Forzano, 2012). Karakteristik responden dalam penelitian ini adalah karyawan-karyawan yang aktif bekerja berumur 18 tahun- 37 tahun, merupakan karyawan tetap, telah bekerja minimal 6 bulan. Pembagian kuesioner dilakuan kepada karyawan di lima wilayah Jakarta: Jakarta Utara, Jakarta Barat, Jakarta Timur, Jakarta Pusat dan Jakarta Selatan. Jumlah sampel yang diperoleh dalam penelitian sebanyak 136 orang. Adapun keterbatasan dari sedikitnya jumlah sampel yang diperoleh dikarenakan saat penyebaran kuesioner tidak semua responden bersedia untuk mengisi kuesioner di saat jam keja, jawaban yang tidak lengkap dan tidak serius dalam mengisi kuesioner. 
Instrumen yang digunakan dalam penelitian ini adalah kuesioner learning agility. Alat ukur digunakan untuk mengukur variabel learning agility disusun oleh peneliti dengan mengacu pada indikator-indikator dari learning agility yang terdapat pada Choices Architect (Eichinger \& Lombardo, 2000). Learning agility termasuk dalam konstruk yang relatif stabil. Dari hasil testrestest koefisien reliabilitas berkisar 0.81 hingga 0.90 (Lombardo \& Eichinger, 2002). Dari hasil metaanalisis yang dilakukan oleh De Meuse (2019) tentang penelitian-penelitian terkait learning agility dan kepemimpinan diperoleh 20 studi dari total 4.897 partisipan diketahui terdapat hubungan antara learning agility dengan kepemimpinan yang sukses. Koefisien korelasi dari 20 studi berkisar $\mathrm{r}=0.08$ sampai $0.91, \mathrm{p}<0.001$. Sehingga, dapat disimpulkan teori mengenai learning agility adalah kredibel. Penyusunan instrumen alat ukur dalam penelitian ini dimulai dengan membuat butir-butir berdasarkan indikator-indikator dari empat dimensi learning agility (Eichinger \& Lombardo, 2000; Eichinger, Lombardo \& Capretta, 2010). Variabel learning agility terdiri dari empat dimensi. Pertama, dimensi mental agility terdiri dari 16 butir dengan contoh butir: "Dalam menyelesaikan permasalahan, saya lebih suka mencari pola dan penyebab bagaimana/mengapa hal tersebut dapat terjadi", "Saya kurang memiliki rasa ingin tahu terhadap hal-hal di sekitar saya.". Kedua, dimensi people agility sebanyak 13 butir terdiri dari "Saya dapat ikut merasakan apa yang dirasakan oleh orang lain", Saya dapat menyesuaikan cara berkomunikasi saya dengan lawan bicara saya". Ketiga, dimensi change agility sebanyak 23 butir dengan contoh butir, "Saya memikirkan solusi dari setiap akibat-akibat yang dapat terjadi dalam pengambilan keputusan", "Saya memilih berada dalam zona nyaman karena saya takut dengan resiko yang akan terjadi.". Keempat, dimensi results agility sebanyak 18 butir dengan contoh butir: "Saya bersemangat untuk memberikan kinerja sebaik-baiknya", "Saya mampu menginspirasi rekan-rekan sekerja atau tim saya untuk bekerja keras". Responden mengisi alat ukur learning agility yang merupakan skala Likert dengan rentang 1 (sangat tidak setuju) sampai 4 (sangat setuju). Peneliti melakukan expert judgment kepada satu orang dosen Psikologi Industri dan Organisasi dan satu orang dosen Psikometri. Kemudian, peneliti melakukan try out alat ukur kepada 38 orang karyawan. Teknik analisis item dengan korelasi butir total dilakukan untuk memperoleh validitas. Butir-butir yang valid adalah butir dengan nilai r> 0,3. Dari hasil uji coba diperoleh dimensi mental agility sebanyak 10 butir valid, change agility terdiri dari 19 butir valid, people agility sebanyak 9 butir valid dan results agility sebanyak 13 butir valid. nilai koefisien reliabilitas internal dari masing-masing dimensi mental agility $=0,793$, dimensi change agility $=0,848$, dimensi people agility $=0,769$ dan dimensi results agility $=0,849$. Total butir valid setelah uji coba berjumlah 51 butir dari jumlah total butir sebelumnya 70 butir.

\section{HASIL DAN PEMBAHASAN}

\section{HASIL}

Pada bagian ini akan dijelaskan hasil penelitian yang terdiri dari statistik deskriptif variabel learning agility dan dimensi-dimensinya dan uji perbedaan learning agility berdasarkan usia dan jenis kelamin.

\section{Gambaran Responden}

Berikut gambaran responden berdasarkan jenis kelamin, usia, pendidikan, lama bekerja dan pekerjaan yang berpartisipasi dalam penelitian ini. 
Tabel 1

Gambaran Responden Penelitian

\begin{tabular}{lccc} 
& Aspek & Jumlah & Persentase \\
\hline Jenis Kelamin & Laki- laki & 49 & 36 \\
& Perempuan & 87 & 64 \\
\hline Usia & $18-25$ & 56 & 41.17 \\
& $26-33$ & 63 & 46.3 \\
Pendidikan & $33-37$ & 17 & 12.5 \\
\hline SMA & 15 & 11 \\
& Diploma & 2 & 1.47 \\
& S1 & 92 & 67.64 \\
& S2 & 27 & 19.85 \\
\hline Pama bekerja & 6 bulan- 1 tahun & 44 & 32.4 \\
& $1-5$ tahun & 55 & 40.4 \\
& 5-10 tahun & 28 & 20.6 \\
& $>10$ tahun & 9 & 6.6 \\
\hline Total & Karyawan Swasta & 100 & 73.5 \\
\hline & Pegawai Negeri & 3 & 2.2 \\
& Profesi (guru, dosen, & 33 & 24.3 \\
konsultan) & 136 & 100 \\
\hline
\end{tabular}

Dari tabel 1 diketahui jumlah responden tebanyak berjenis kelamin perempuan (63.2\%), usia terbanyak berkisar antara 26- 33 tahun $(46.3 \%)$. Mayoritas responden memiliki pendidikan pendidikan terakhir S1 (67.64\%) dengan lama kerja 1-5 tahun (40.4\%) dan pekerjaan karyawan swasta $(73.5 \%)$ mencakup marketing, HR, IT, business development, administrasi dan lainnya.

\section{Gambaran Learning Agility}

Gambaran norma dari learning agility menggunakan perbandingan mean hipotetik dan empirik. Nilai mean hipotetik diperoleh dari nilai rata-rata kemungkinan respon jawaban. Alat ukur learning agility menggunakan reson jawaban 1-4, nilai rata-rata hipotetik aalah 2.5. Nilai mean empirik diperoleh dari skor total dibagi dengan jumlah butir. Apabila $\mathrm{M}_{\mathrm{e}}>2.5$ maka tergolong tinggi, namun bila $\mathrm{M}_{\mathrm{e}}<2.5$ maka tergolong rendah. Hasil nilai statistik dan penormaan learning agility pada tabel di bawah ini:

Tabel 2

Nilai Statistik Learning Agility

\begin{tabular}{lcc}
\hline Learning agility & Skor Hipotetik & Skor Empirik \\
\hline Skor tertinggi (Max) & 204 & 191 \\
Skor terendah (Min) & 51 & 118 \\
Mean & 127.5 & 154.90 \\
Standar Deviasi & 25.5 & 16.23 \\
\hline
\end{tabular}


Pada tabel 2. tampak bahwa skor rata-rata empirik lebih tinggi dari skor rata-rata hipotetik.

Hal ini menunjukkan skor learning agility responden tergolong tinggi.

Tabel 3

Kategori Deskriptif Learning Agility

\begin{tabular}{ccc}
\hline Kategori & Frekuensi & Persentase \\
\hline Rendah & 5 & $3.7 \%$ \\
Tinggi & 131 & $96.3 \%$ \\
\hline
\end{tabular}

Pada tabel 2, jumlah responden skor learning agility yang tergolong tinggi sebanyak 96.3 persen dan kategori rendah sebanyak 3.7 persen.

Tabel 4

Nilai Statistik Dimensi-Dimensi Learning Agility

\begin{tabular}{lllll}
\hline Dimensi & Min & Max & Mean & Standar Deviasi \\
\hline Mental Agility & 2.1 & 3.9 & 3.11 & 0.39 \\
Change Agility & 2.21 & 4.32 & 3.04 & 0.36 \\
People Agility & 1.78 & 6.22 & 2.93 & 0.48 \\
Results Agility & 1.85 & 4 & 3.04 & 0.39 \\
\hline
\end{tabular}

Dari hasil perhitungan skor rata-rata dimensi learning agility, nilai skor rata-rata paling tinggi adalah dimensi mental agility $(\mathrm{M}=3.11)$ dan paling rendah adalah people agility $(\mathrm{M}=2.93)$. Skor tinggi pada mental agility menunjukkan generasi milenial melihat permasalahan dengan sudut pandang yang lebih baru, nyaman dengan kompleksitas, ambiguitas dan dapat menjelaskan pemikirannya kepada orang lain. Skor yang rendah pada people agility menunjukkan generasi milenial kurang dapat memahami dirinya sendiri, belajar dari pengalaman, dan resilien terhadap tekanan.

Peneliti melakukan uji independent t-test untuk mengetahui perbedaan learning agility dan dimensi-dimensi learning agility generasi milenial berdasarkan jenis kelamin.

Tabel 5.

Perbedaan Learning Agility Dan Dimensi Learning Agility Berdasarkan Jenis Kelamin

\begin{tabular}{|c|c|c|c|c|c|}
\hline \multirow[t]{2}{*}{ Variabel } & \multicolumn{2}{|c|}{ Mean } & \multicolumn{3}{|c|}{ Nilai } \\
\hline & Pria & Wanita & & $t$ & $p$ \\
\hline Learning agility & 153.10 & 156 & - & 0.97 & 0.33 \\
\hline Mental agility & 20.65 & 31.43 & & -1.13 & 0.26 \\
\hline Change agility & 57.4 & 58 & - & 0.5 & 0.62 \\
\hline People agility & 25.5 & 26.94 & & -1.9 & 0.061 \\
\hline Results agility & 39.5 & 39.5 & & 0.002 & 0.1 \\
\hline
\end{tabular}


Dari tabel 5, diketahui tidak ada perbedaan learning agility antara pria dan wanita $(t=-0.97, p=$ $0.33)$. Begitupula, tidak ada perbedaan dari dimensi mental agility $(t=-1.13, p=0.26)$, change agility $(t=-0.5, p=0.62)$, people agility $(t=-1.9, p=0.061)$, results agility $(t=0.002, p=0.1)$ antara pria dan wanita.

Peneliti melakukan uji beda dengan one-way ANOVA untuk mengetahui perbedaan learning agility berdasarkan usia. Kelompok usia terbagi menjadi tiga yaitu usia 18-25 tahun, 26-33 tahun, dan 33-37 tahun.

Tabel 6

Perbedaan Learning Agility Dan Dimensi-Dimensi Learning Agility Berdasarkan Usia

\begin{tabular}{lccccc}
\hline \multirow{2}{*}{ Variabel } & \multicolumn{2}{c}{ Mean } & \multicolumn{2}{c}{ Nilai } \\
\cline { 2 - 6 } & $18-25$ tahun & $26-33$ tahun & $33-37$ tahun & $F$ & 0.34 \\
\hline Learning agility & 155.18 & 153.77 & 157.04 & 0.71 \\
Mental agility & 31.1 & 30.77 & 32.2 & 1.15 & 0.31 \\
Change agility & 58 & 57.5 & 58 & 0.076 & 0.92 \\
People agility & 27 & 26 & 26.65 & 1.01 & 0.37 \\
Results agility & 39.16 & 39.6 & 40.13 & 0.31 & 0.72
\end{tabular}

Dari tabel 6. diperoleh hasil tidak ada perbedaan learning agility berdasarkan usia $(F=0.31$, $p=0.71)$. Pada dimensi-dimensi dari learning agility juga tidak ada perbedaan mental agility $(\mathrm{F}=$ $1.15, \mathrm{p}=0.31)$, change agility $(\mathrm{F}=1.076, \mathrm{p}=0.92)$, people agility $(\mathrm{F}=1.01, \mathrm{p}=0.37)$, results agility $(\mathrm{F}=0.31, \mathrm{p}=0.72)$ berdasarkan usia.

\section{PEMBAHASAN}

Dari hasil diketahi skor learning agility karyawan berada di kategori tinggi. Hal ini menunjukkan karyawan memiliki mental agility, change agility, people agility, dan results agility yang relatif tinggi. Walaupun demikian, pada skor rata-rata ditemukan mental agility karyawan generasi milenial paling tinggi diikuti change agility dan results agility dengan skor rata-rata yang sama, dan skor rata-rata people agility paling rendah. Dalam mental agility, menggambarkan generasi milenial terbuka melihat permasalahan dari sudut pandang yang baru yang mana hal ini tidak terlepas dari kreativitas yang dimiliki seseorang. Dari hasil penelitian sebelumnya oleh Archiyanti (2017) kepada karyawan generasi milenial diperoleh sikap proaktif memiliki korelasi yang paling kuat terhadap kreativitas disusul oleh modal psikologis dan dukungan organisasi. Sikap proaktif, modal psikologis, dan dukungan organisasi berkontribusi sebesar $46.9 \%$ terhadap kreativitas generasi milenial. Dengan kata lain, generasi milenial yang proaktif cenderung akan lebih dapat memiliki ide dan melihat masalah dari perspektif yang baru.

Change agility pada karyawan milenial yang cukup tinggi menggambarkan seseorang yang berusaha untuk berinovasi dan berubah dengan cepat, senang mencoba hal-hal baru, mudah menerima perubahan dan dapat mengantisipasi konsekuensi di masa depan (De Meuse, Dai \& Hallenbeck, 2010) dapat dijelaskan dalam penelitian sebelumnya Ludviga dan Sennikova (2016) mengenai reaksi terhadap perubahan dari generasi yang berbeda yaitu generasi Baby Boomers, generasi $\mathrm{X}$ dan generasi $\mathrm{Y}$. Reaksi terhadap perubahan berupa tanggapan dari ketiga generasi 
mengenai perubahan. Hasil uji statistik ditemukan adanya perbedaan signifikan reaksi terhadap perubahan dari ketiga generasi. Generasi milenial memiliki reaksi yang lebih positif daripada generasi X dan generasi Baby Boomers. Lebih lanjut, resistensi terhadap perubahan ditemukan sebesar $4.5 \%$ pada generasi Baby Boomers, $18.7 \%$ pada generasi $\mathrm{X}$ dan $8.2 \%$ pada milenial. Hal ini disebabkan karyawan generasi Baby Boomers lebih kurang tertarik terhadap perubahan daripada generasi yang lebih muda, sedangkan di sisi lain generasi milenial lebih mampu beradaptasi terhadap perubahan dan menganggapnya sebagai sebuah norma (Buahene, 2013; Bourne, 2009 dalam Ludviga \& Sennikova, 2016).

Hasil penelitian diketahui generasi milenial memiliki results agility yang tergolong cukup tinggi. Results agility berkaitan dengan kemampuan membangun kinerja yang tinggi, memiliki dorongan atau motivasi yang kuat dalam penyelesaian tugas, dan dapat mencapai tujuan terlepas dari halangan-halangan yang ada (De Meuse, Dai \& Hallenbeck, 2010). Dalam penelitian sebelumnya generasi milenial adalah generasi yang bertumbuh dengan orangtua yang memperhatikan anak-anaknya dan membangun harga diri anak, sehingga karakteristik dari generasi ini adalah harapan untuk dikenal sama seperti rekan-rekan kerjanya dan ingin terlibat dalam lingkungan kerja yang beragam dan mendorong partisipasi dalam kerja tim (Class 2007; Ballone, 2007; Hoole \& Bonnema, 2015). Generasi milenial merupakan generasi yang fokus pada prestasi (achievement oriented). Hal ini sejalan dengan penelitian Hauw dan Vos (2010) menemukan generasi milenial memiliki ekspektasi yang tinggi akan konten pekerjaan, perkembangan karir, pelatihan, penghargaan finansial dan job security. Ekspektasi ini dipengaruhi oleh pengaruh generasi yang mana generasi milenial lahir bersamaan dengan teknologi baru, transisi ekonomi yang lebih baik sehingga membentuk kepribadian dan nilai yang mereka miliki. Sehingga, generasi milenial akan bersedia memberikan usaha ekstra, bekerja hingga diluar jam kerja, mengurangi waktu sosial mereka untuk membantu organisasi. Akan tetapi, di penelitian lainnya, Hoole dan Bonnema (2015) mengenai work engagement dari tiga generasi yaitu Baby Boomers, generasi X dan generasi Y (milenial), diketahui terdapat hubungan antara work engagement dengan makna kerja. Terdapat pula perbedaan signifikan engagement dari ketiga generasi. Generasi Baby Boomers adalah generasi yang paling terlibat dibandingkan generasi $\mathrm{X}$ dan generasi $\mathrm{Y}$, dengan atribut ambisius, kompetitif, dedikasi dan bersemangat.

Selanjutnya, dimensi people agility karyawan milenial dengan skor paling rendah dapat dijelaskan dari penelitian sebelumnya. People agility terkait dengan bagaimana seseorang merespon orang lain dalam situasi yang berbeda, fleksibel dan dapat menyesuaikan diri terhadap kebutuhan (De Meuse, Dai \& Hallenbeck, 2010). Generasi milenial tumbuh seiring dengan munculnya perkembangan teknologi sehingga dalam berkomunikasi mereka cenderung instan dengan menggunakan teknologi. Hal ini akan berpengaruh dengan cara generasi milenial berinteraksi dengan orang lain di tempat kerja yang berbeda generasi. Kebutuhan milenial atas komunikasi yang instan dan terus menerus akan menimbulkan terganggunya alur kerja di tempat kerja (Meola, 2016). People agility juga terkait dengan resiliensi generasi milenial di bawah tekanan, Chakradhar, Waddil dan Kleinhans (2018) yang meneliti resiliensi multigenerasi di lingkungan kerja akademik di Amerika menemukan resiliensi dari kelompok Baby Boomer diprediksi oleh tekanan waktu, tempo kerja dan makna pekerjaan, mereka tidak sering tertinggal dalam pekerjaan dan lebih memiliki waktu untuk mengerjakan tugas dan bekerja dalam kecepatan tinggi sepanjang waktu. Resiliensi generasi $\mathrm{X}$ diprediksi dengan rendahnya tekanan waktu dan memaknai pekerjaan lebih baik. Mereka juga memiliki kepercayaan yang lebih baik terhadap manajemen. Resiliensi generasi milenial sendiri diprediksi oleh kesempatan yang diperolehnya untuk mengambil inisiatif dan mengembangkan keterampilan. Selain itu, ketika 
tingkat kepercayaan vertikal antara karyawan dengan managemen rendah, resiliensi mereka semakin lebih baik. Hal ini dikarenakan generasi milenial lebih percaya diri dan tidak merasa kondisi tersebut penting untuk kesuksesannya (Hannay \& Fretwell dalam Chakradhar, Waddil \& Kleinhans, 2018). Generasi milenial umumnya mencari dukungan dari atasan dan lebih menyukai informasi yang terbuka mengenai arah organisasi (Myers \& Sadaghiani, 2010). Penelitian Walden, Jung dan Westerman (2017) menemukan persepsi komunikasi karyawan berasosiasi positif dengan job engagement dan komitmen organisasi. Akan tetapi, terkait dengan keinginan untuk belajar dan interaksi dengan generasi di atasnya, hasil survey TeleTech Consulting's (2017) menyebutkan generasi milenial memiliki sudut pandang yang hampir mirip dengan generasi yang lebih tua. Generasi milenial terutama memiliki keinginan yang lebih kuat dan lebih konsisten untuk belajar dibandingkan generasi lainnya, namun dari hasil focus group discussion milenial tidak diberikan kesempatan yang banyak untuk belajar dan bertumbuh. Hal ini memungkinkan menjadi hambatan generasi milenial dalam aspek people agility.

Hasil uji perbedaan diketahui tidak ada perbedaan learning agility berdasarkan jenis kelamin. Hal ini sejalan dengan penelitian sebelumnya De Meuse, Dai, Hallenbeck, dan Tang (2008), bahwa skor learning agility tidak berhubungan dengan jenis kelamin, tetapi manager perempuan memiliki skor people agility yang lebih tinggi dibandingkan manager laki-laki. Berbeda dengan penelitan sebelumnya, dalam penelitian ini skor rata-rata mental agility, people agility dan change agility responden perempuan lebih tinggi daripada responden laki-laki. Hal ini dapat dikarenakan jumlah responden perempuan yang lebih banyak (64\%) daripada responden laki-laki (36\%). Sedangkan untuk results agility skor rata-rata dari perempuan dan laki-laki adalah sama. Hal ini dikarenakan perempuan milenial juga mendapatkan paparan yang sama terhadap dunia melalui kecanggihan teknologi, paparan terhadap multikulturalisme daripada generasi sebelumnya sehingga memberikan inspirasi bagi mereka menjadi ambisius dan penuh harapan untuk berprestasi sama seperti laki-laki. Perempuan milenial juga dibesarkan untuk berorientasi pada tujuan dan prestasi (Chu, 2014). Skor learning agility juga ditemukan tidak ada perbedaan berdasarkan usia. Sesuai dengan penelitian sebelumnya oleh De Meuse, Dai, Hallenbeck dan Tang (2008), uji perbedaaan statistik ditemukan tidak adanya perbedaan nilai skor rata-rata pada kelompok usia yang berbeda.

\section{KESIMPULAN DAN SARAN}

\section{KESIMPULAN}

Kesimpulan dalam penelitian ini adalah para karyawan yang merupakan generasi milenial memiliki leaning agility yang cenderung tinggi. Karyawan generasi milenial memiliki skor mental agility yang paling tinggi, diikuti change agility dan results agility yang memiliki skor rata-rata yang sama dan people agility dengan skor rata-rata paling rendah. Selain itu, tidak terdapat perbedaan learning agility bedasarkan usia dan jenis kelamin karyawan generasi milenial.

\section{SARAN}

Saran untuk penelitian selanjutnya adalah melakukan penelitian ulang dengan alat ukur yang sama dengan membandingkan generasi milenial dengan generasi sebelumnya yaitu generasi Baby Boomers dan generasi X di Indonesia karena masih minimnya penelitian dengan sampel di Indonesia. Selain itu, dengan melihat dari keterbatasan penelitian dalam jumlah sampel, disarankan penelitan selanjutnya menambah jumlah responden lebih banyak. Kelemahan lainnya 
adalah alat ukur dari learning agility yang digunakan dalam penelitian ini masih perlu dikembangkan di penelitian-penelitian selanjutnya agar diketahui konsistensi reliabilitasnya. Dalam pembautan aitem dan pengisian kuesioner, peneliti harus melihat adanya kemungkinan faktor social desirability dari responden untuk memberikan kesan yang positif tentang dirinya.

Saran bagi organisasi dengan hasil penelitian ini diharapkan organsiasi memanfaatkan potensi yang dimiliki oleh para generasi milenial yang mana generasi ini memiliki keinginan kuat untuk berkembang, belajar, siap akan perubahan namun juga menginginkan fleksibilitas dan tantangan. Dengan perhatian berupa mentoring dan coaching dari pihak organisasi tempat karyawan bekerja, learning agility generasi milenial dapat membantu organsiasi menyiapkan organisasi talent-talent untuk memimpin organisasi di kemudian hari.

\section{Ucapan Terima Kasih}

Penelitian ini merupakan penelitian hibah dari Universitas Bunda Mulia. Oleh karena itu peneliti mengucapkan terima kasih kepada Universitas Bunda Mulia atas dukungannya dalam penelitian dosen. Tidak lupa ucapan terima kasih juga untuk para responden penelitian yang bersedia partisipasi dalam penelitian dan asisten peneliti yang telah membantu penelitian ini.

\section{DAFTAR PUSTAKA}

Archianti, P. (2017). Memprediksi kreativitas generasi milenial di tempat kerja. Jurnal Ilmiah Penelitian Psikologi Kajian Empiris \& Non-Empiris, 3(2), 61-68. https://doi.org/https://doi.org/10.22236/JIPP-36.

Ballone, C. (2007). Consulting your clients to leverage the multi-generational workforce. Journal of Practical Consulting, 2(1), 9-15.

Chakradhar, K., Waddill, P. J., \& Kleinhans, K. A. (2018) Resilience and

the multigenerational academic work environment in the United States, Journal of Intergenerational Relationships, 16(4), 374-394. doi: 10.1080/15350770.2018.1489332

Chu, T. (2014). How millennial women are redefining leadership at work. Retrieved September 15 2019, from https://www.theguardian.com/women-in-leadership/2014/jun/20/millennialwomen-redefining-leadership-confidence-gap

Codreanu, A. (2016). A VUCA action framework for a VUCA environment, leadership and solutions. Journal of Defense Resources Management, 7(2), 31-38.

Dai, G., De Meuse, K. P., Clark, L. P., \& Cross, J. (2011). Criterion-related validation of the Choices Assessment: Findings from two recent studies (Tech. Rep. No.). Minneapolis, $\mathrm{MN}$ : Korn Ferry International.

De Meuse, K. P. (2019). A meta-analysis of the relationship between learning agility and leader success. Journal of Organizational Psychology, 19(1), 25-34.

De Meuse, K.P., Dai G., dan Hallenbeck, G. S. (2010). Learning agility : A construct whose time has come. Consulting Psychology Journal, 2(2), 119-130.

De Meuse, K. P., Dai, G., Hallenbeck, G., \& Tang, K. (2008). Global talent management: Using learning agility to identify high potentials around the world. Los Angeles: Korn/Ferry International.

De Rue, D.S., Ashford, S.J., \& Myers, C.G. (2012). Learning agility: In search of conceptual clarity and theoretical grounding. Industrial and Organizational Psychology, 5, 258-279. 
Eichinger, R. W., \& Lombardo, M. M. (2004). Learning agility as a prime indicator of potential. Human Resource Planning, 27(24), 12-15.

Frey, W H. (2018). The millenial generation : A demoraphic bridge to America's diverse future. Washington : Metropolitan Policy Program at Brookings.

Glass, A. (2007). Understanding generational differences for competitive success. Industrial and Commercial Training, 39(2), 98-103. https://doi.org/10.1108/00197850710732424

Hari, A. (2017). Memahami generasi milenial penting dilakukan untuk mendukung perusahaan. Retrieved March 5 2018, from http://www.intipesan.com/memahami-generasi-millenialpenting-dilakukan-untuk-mendukung-kemajuan-perusahaan/

Hoole, C., \& Bonnema, J. (2015). Work engagement and meaningful work across generational cohorts. SA Journal of Human Resource Management, 13(1), 1-11. https://doi.org/10.4102/sajhrm.v13i1.681

De Hauw, S., \& De Vos, A. (2010). Millennials' career perspective and psychological contract expectations: Does the recession lead to lowered expectations?. Journal of Business and Psychology, 25(2), 293-302. doi:10.1007/s10869-010-9162-9

Kornelsen, J. (2019). The quest to lead (with) millenials in VUCA- world: Bridging the gap between enerations. In J. (Kobus) Kok, S. C van den Heuvel (eds), Leading in a VUCA World, Contributions to Management Science (pp 27-41). https://doi.org/10.1007/978-3319-98884-9_2

Ludviga, I., \& Sennikova, I. (2016). Organisational change: Generational differences in reaction and commitment. $9^{\text {th }}$ International Scientific Conference Business and Management 2016, 1-10. https://doi.org/10.3846/bm.2016.10

IDN Research Institute (2019). Indonesia Millenial Report 2019. Retrieved $5^{\text {th }}$ March 2018 from https://www.idntimes.com/indonesiamilenialreport2019

KPMG International. (2017). Meet The Millenials. UK: KPMG LLP.

Meola, C. C. (2016). Addressing the needs of the millennial workforce through equine assited learning. Journal of Management Development, 35(3), 294-303. doi:10.1108/jmd-08-20150110

Mitchinson, A., \& Morris R. (2014). Learning About Learning Agility. Center for Creative Leadership. Retrieved April 22 2018, from https://www.ccl.org/articles/whitepapers/learning-about-learning-agility.

Myers, K. K., \& Sadaghiani, K. (2010). Millenials in the workplace: A communication perspective on millenials' organizational relationships and performance. Journal Business Pscyhology, 21, 225-238. doi: 10.1007/s10869-010-9172-7

Persiapan HRD Menghadapi VUCA World. (2015). Retrieved March 5 2018, from https://portalhr.com/people-management/persiapan-hrd-menghadapi-vuca-world/

Pinzaru, F., Vatamanescu, E- M., \& Mitan, A. (2016). Millenials at work: Investigating the specificity of generation $\mathrm{Y}$ versus other generations. Management Dynamic Knowledge Economy, 4(2), 173-192.

Pitt-Catsouphes, M. P., Matz-Costa, C., Besen, E. (2009). Workplace flexibility: Findings from age and generations. Retrieved September 10 2019, from https://www.bc.edu/content/dam/files/research_sites/agingandwork/pdf/publications/IB19 WorkFlex.pdf

Prabowo, A., Latifah, D. A., \& Rahmadiani, N. D. (2017). Profil kepribadian generasi Y. Prosiding Temu Ilmiah Nasional APIO 2017 "Mengelola dan Melejitkan Generasi Y di Era Digital”, pp. 12-23.

Sarkar, A. (2016). We live in a VUCA World: the importance of responsible leadership. Development and Learning in Organizations, 30(3), 9-12. https://doi.org/10.1108/DLO07-2015-0062 
Strauss, W. \& Howe, N. (1991). Generations: The history of America's future, 1584 to 2069. NY: William Morrow and Company Inc.

TeleTech Consulting. (2017). Tap into the milenial mindset. Retrieved March 8 2018, from https://www.ttec.com/articles/tap-milenial-mindset.

Walden, J., Jung, E. H., \& Westerman, C. Y. K. (2017). Employee communication, job engagement, and organizational commitment: A study of members of the Millenial Generation. Journal of Public Relations Research, 29(2-3), 73-89. doi: 10.1080/1062726x.2017.1329737

Wicaksono, D. A. (2017). Mengelola generasi Y di tempat kerja tantangan bagi Psikologi Industri dan Organisasi. Prosiding Temu Ilmiah Nasional APIO 2017 "Mengelola dan Melejitkan Generasi Y di Era Digital”, pp. 323-331.

Widhianingtanti, L. T. (2017). Fenomena Gen Y Sulit Diatur dan Tidak Loyal ? Prosiding Temu Ilmiah Nasional APIO 2017 : Mengelola dan Melejitkan Talenta Gen Y di Era Digital. Jakarta : Himpsi. 